International Journal of Instruction e-ISSN: 1308-1470 • www.e-iji.net
October $2018 \bullet$ Vol.11, No.4

p-ISSN: 1694-609X

pp. 353-374

Received: 07/03/2018

Revision: 08/06/2018

Accepted: 14/06/2018

\title{
Perceptions of Secondary School Students of the Social Science Class: A Study in Three Colombian Institutions
}

\author{
Nancy Palacios Mena \\ Dr., University of the Andes, Colombia,n.palaciosm@uniandes.edu.co
}

\begin{abstract}
The objective of this article is to analyze the perception of secondary school students of their social science class in three different Colombian educational institutions. It is important to identify the significant aspects valued by students concerning their experience in the aforementioned class and to describe analytically the meaning that they give to the teaching and learning of the subject. A mixed methodological design was used that allowed the processing of quantitative (survey) and qualitative (interviews) data. The systematization of these data was carried out with the Nvivo and Stata programs. A prevalence of negative over positive perceptions was observed as well as the students' low motivation for the subject, due to non-significant experiences in their classes. The students consider that the class is important and could help them enhance their skills and understanding of the world in which they live; however, the methodologies used, the contents, and the evaluation procedures are not the most pertinent, to which they add some conflicts in the relationships with their teachers.
\end{abstract}

Keywords: secondary school, social science teaching, perceptions, school experience

\section{INTRODUCTION}

The objective of this article is to analyze how secondary school students perceive a social science class in three different Colombian educational institutions. It is important to identify the significant aspects valued by students concerning their experience in the aforementioned class, and to describe analytically the meaning that they give to the teaching and learning of the subject.

The text seeks to answer questions concerning both the way students in their last year of secondary school perceive their social science class and which teaching and learning processes have prompted these perceptions. In the same stance as that of San Fabian (1988), the article deals with studying "perceptual processes that take place inside the classroom. Its main interest is to explain the meanings that derive from the school context, that is, schooling as an experience" (p.8). Our starting point is based on assumptions, similar to those made by other researchers, which indicate that students' perceptions and evaluations change throughout their time in school in a process of

Citation: Palacios, N. (2018). Perceptions of Secondary School Students of the Social Science Class: A Study in Three Colombian Institutions. International Journal of Instruction, 11(4), 353-374. https://doi.org/10.12973/iji.2018.11423a 
formation that shapes the meaning of the experience of being a student, and also the meanings attributed to knowledge, teaching and learning (Delgado, 2012).

Specifically, in social sciences, different works on students' perceptions have come to the conclusion that these are closely linked to the teaching methods used in class and influenced by family and social experiences (Fuentes, 2002). According to Mateos (2009), the perception that students have of their school has a direct or indirect influence on matters such as social relationships and school integration. "Problems such as failure in school, communication difficulties in the educational relationship, or school maladjustment can hide a negative image of the faculty, peers, of themselves, and in general, of the school itself' (p.288).

Consequently, the article's perspective recognizes students' perceptions as testimonies that attest to a knowledge that provides insights and reflections of how it was acquired. This perspective coincides with that of authors such as Pórtela, Martínez and García (2014) for whom "the voice of students is rich in experiences regarding teaching and learning, and in expressing the conditions in which they develop. It attains an understanding of valuable insights and reflective judgments about that environment, that deserve to be heard" (p. 123).

\section{Theoretical reference}

\section{Students' perceptions}

As stated by Schutz (1962) and San Fabian (1988), an institution cannot be understood without considering what it means for the individuals that orient their behavior with respect to its existence. Hence, if the purpose of a school is to influence individuals, their opinion cannot only condition the effectiveness of such a process, but it also constitutes one of its main effects.

For Giménez, Ávila and Ruiz (2007); Thornton (1991); Evans (1993); and Pages (1993), studies on conceptions are a priority in the social sciences educational research. From Rudduck's (2006 and 2007) perspective, it has been historically important to recognize students' perceptions because, besides being directly involved in the educational processes, they have valuable contributions and relevant information to share.

Ever since San Fabián (1988), many studies on students' perceptions about their schools have developed in the fields of psychology of learning and interpersonal relationships. They have as referents theories of attribution, social climate and motivation. San Fabián (1988) emphasizes that these studies have focused on processes of perception of subjects, teaching behaviors and strategies, expectation effect, behavioral causes, classroom atmosphere, teacher demands, and differential treatment of classmates.

According to Pórtela, Martínez and García (2014), although many teachers consult their students about their interests, the contents of their classes and even of their teaching, it would be essential that these exercises go beyond mere consultation and provide information about school and education. Rudduck and McIntyre (2007), cited by Pórtela, Martínez and García (2014), postulate the importance of adopting "an approach 
that is: more deliberate, intentional and well-planned, with the clear and firm purpose of listening to the ideas that students have of their education in order to improve it; broad in order to invite students to speak openly about their experiences regarding education in general and not about specific aspects; and explicit in the sense that students see clearly that their judgments are valued and can be taken into account" (p.112).

Expert witnesses, silent witnesses and pedagogical voices are some of the designations that researchers have given to students in works in which they have included their voices about their experiences in the school context. Rudduck and Flutter (2000) Rudduck and McIntyre (2007) and Pórtela, Martínez and García, (2014), consider students to be expert witnesses of education and of the centers they attend. When they have questioned them, they have recognized their experience and expertise to analyze, reflect, understand and make judgments about the education they receive, thus, contributing to its improvement. Smyth (2007) and Smyth and McInerney (2012), emphasize that, although in most cases, students are silent witnesses because their testimonies are heard but go unattended and are not taken into account, the relevance of such testimonies lies in that they stem from those directly affected by the dysfunctions and injustices that take place in the classrooms. Arnot and Reay (2007) call "pedagogical voices" those of students whose experience in a school institution empowers them to change the tendency to neglect what students think and to modify the regulatory system and the prevailing teaching dynamics.

\section{What do students' perceptions indicate?}

Studies on students' perceptions are valid because they are a source of information about what happens at school. Mateos (2009) points out that their perception of school life largely determines their identity as students, their interaction with peers and teachers, their academic performance, and in general, their integration or not to the educational institution. "Exploring the meaning that school life has for the student, not only gives information about what is happening in that scenario but also about the subjective dimension from which the educational actors give meaning to the school reality" (Mateos, 2009, p.286).

Consequently, students' perceptions are the product of school experiences, and these are intimately related to the system of relationships established in the school premises and its environment. According to Mateos (2009) and Lozano (2005), students' perceptions are the product of a crossing of factors that become more complex because of their interpretations. Both positive and negative experiences are crystallized in recurrent and socially shared arguments about the meaning and purpose of the school.

Due to the different dimensions and elements that constitute the students' school experience, the meaning and value given to the institution is not only defined in terms of satisfaction and dissatisfaction, pleasure or dislike. Therefore, it will be necessary to take into account the elements that condition the students' perception, as well as the consequences that this image has in the development of their school life, at an academic, psychological and social level (Mateos, 2009, p.288). 
For San Fabián and Mateos, the utilitarian perspective of the school is the most recurrent aspect in the students' perceptions; these become clearer as students grow up and attend more advanced courses since they consider the school to be the main means to obtain a job or better educational levels.

Regarding the negative perceptions, Mateos (2009) determined that frequently, students' subjective expectations, needs, and interests, do not correspond to the needs that are perceived by the school institution. The findings of Reeves (1978) and Rappoport (1986) indicate that the increase in student dissatisfaction as schooling progresses is due to the clearer and more dominant perception of their future at work and social status, which is greatly conditioned by the school. For these authors, the attitude towards school deteriorates because of certain concurrent factors: The attitudes and activities of the teachers who distribute stimuli in a discriminatory manner, the relationship between the family and the school environment, influenced by the child's belonging to a certain social class, and the quality of what the child learns.

For San Fabián (1988), the reified character of the school, particularly in its compulsory cycles, favors neither self-reflection nor an essential examination of it. According to him, this is because schools have not sought to promote processes of internal analysis; on the contrary, the real changes are planned and organized by external administrative mechanisms.

\section{Students' perceptions of their social science class}

As mentioned before in the introduction, the article is focused on analysing the way last year secondary school students perceive their social science class in three Colombian educational institutions. This analysis is based on the principle that perceptions are not static, but on the contrary, as stated by Delgado (2012), they are modified throughout a training process that shapes the meaning of the school experience and along with it, the meanings attributed to knowledge, teaching and learning.

We also agree with Delgado (2012) in that teaching and other institutional practices establish principles that give meaning to the different factors that make up the school. However, each student interprets those meanings mediated by the type of relationship that he/she has established with knowledge, because beyond any adjustment to institutional conditions and routines, students assume positions with respect to a set of instituted meanings that underlie the most common ways of working with knowledge.

In the field of social sciences, and more specifically in history, according to Fuentes (2002), it is useful and necessary to perform further research in order to have a better understanding of the students' opinion about the topic as a discipline and as a school subject. This is particularly useful both for those in charge of designing the curricula, as for teachers in this area who so often face difficulties in working with basic concepts of history with groups of teen-agers whose reasoning schemes are very complex and for whom topics and misconceptions about the past weigh heavily. Fuentes's work has allowed him to establish that the age of the students and the methodology used in the teaching and learning activities are the fundamental factors that determine the students' understanding and perception of the past. 
Also in the field of history, the works of Aldrich (19870, Lee and Asbhy (1987), Shemilt (1987), Cooper (1992), Seixas (1993) and Vansledriht and Christine (1998), in addition to identifying evolutionary stages in students' perceptions when studying the past, demonstrated the close relationship established between the students' vision of history and the teaching methods in the classroom. These authors mostly agree that the perception of history as a close and exact knowledge of past events can change when students are exposed to new methodologies and new conceptions of historical knowledge.

Regarding the study of geography, research carried out by Secil (2014); Bar-Gal and Sofer (2010); Lumpkin, Achen and Dodd (2015); Bowlick, and Kolden (2013) and Saleh and Gandy (2016), indicates that students' perceptions raise the need to create a student-centered environment. They emphasize that an attractive and pleasant learning environment for students impacts in a positive way their perceptions of learning. These researchers have also identified differences between the students' perceptions of the importance of studying geography and the curricular orientations of that subject, evidencing that the objectives and goals of the official curriculum do not always coincide with the interests of the students.

\section{METHOD}

A mixed methodological design was used to triangulate qualitative and quantitative data collection techniques (Grant, 2001; Barca, 2005; Barton, 2005) and to perform a combination of varied strategies and techniques in the context of an empirical and systematic search of the reality (Kerlinger, 2002; Gómez and Miralles, 2015; Saiz and López-Facal, 2015). The alternation of quantitative and qualitative data made it possible to configure a specific system of categories of analysis and capture a rich and diverse image that reflects the heterogeneity of what happens in the classrooms.

\section{Participants}

The 275 participants, whose ages range between 15 and 18, are last grade students in three different secondary public schools of the city of Ibagué, Colombia (see Table 1). We decided to work with the $11^{\text {th }}$ grade students because they have a more complete vision of what social sciences training has been during the five years of primary and the six years of secondary school.

Table 1

Research participants

\begin{tabular}{ll}
\hline Educative institution & Number of students \\
\hline Institution I & 73 \\
Institution II & 98 \\
Institution III & 104 \\
\hline Total of students & 275 \\
\hline
\end{tabular}

Author's elaboration

The participating educational institutions were chosen at random from the database of the Instituto Colombiano de Evaluación de la Educación - ICFES (Colombian Institute 
for Educational Evaluation). In the search for these educational institutions two criteria were taken into account: first, they had to be public schools and second, the results in the Saber 11 Test $^{1}$ had to be heterogeneous. As illustrated in Table 2, a school was chosen from the top positions, another from the middle and a third one from the bottom, according to the averages obtained in the Saber 11 Tests of 2015, 2016 and 2017.

Table 2

Classification of participant educative institutions depending on their position in the city and they average in the social studies Saber test.

\begin{tabular}{ccccccc} 
& \multicolumn{2}{c}{ Year $2015^{*}$} & \multicolumn{2}{c}{ Year $2016^{* *}$} & \multicolumn{2}{c}{ Year 2017 } \\
Educative Institutions & Positio & Average & Positio & Average & Positio & Average \\
& $\mathrm{n}$ & $\mathrm{CS}$ & $\mathrm{n}$ & $\mathrm{CS}$ & $\mathrm{n}$ & CS \\
Institución I & 5 & 58 & 3 & 59 & & 60 \\
Institución II & 11 & 52 & 19 & 53 & & 51 \\
Institución III & 25 & 50 & 35 & 52 & & 54 \\
\hline
\end{tabular}

*In 201536 public schools were evaluated.

**In 201642 public schools were evaluated.

*** In 201645 public schools took the test.

Source: Icfes $(2015,2016$ y 2017). Author's elaboration.

After the random search of the Institutions, an invitation was sent indicating the research objectives and the need to obtain authorization for students to participate in the survey and interviews. Once the informed consents of both students and parents were filled out, we proceeded to apply the instruments.

\section{Variables}

Some variables were defined to account for students' perceptions of teaching, learning, knowledge and assessment in the social science class. The variables were the following: the teacher's methodology, the class opinion, the motivation to participate in activities, the evaluation and Saber Test, the teacher's opinion, and the importance and usefulness of the contents of the class.

\section{Information gathering instruments}

Quantitative data: The survey was applied to $98 \%$ of the students, leaving out only those who did not attend school on that day. The survey questionnaire was divided into four modules: Personal information, social sciences as a field of knowledge, social science as a school subject, and the evaluation of what was learned. For the design of the questionnaire, the following were consulted: the National Administrative Department of

\footnotetext{
${ }^{1}$ The Saber 11 Test is the test that ICFES performs for students who complete secondary education. This test is one of the indicators of the quality of education of the institutions and the selection criteria used by most of the country's universities.
} 
Statistics DANE (2017) educational data collection model; the survey of school coexistence and circumstances that affect it for students from $5^{\text {th }}$ to $11^{\text {th }}$ grades in Bogota, DANE (2011); the Vallejo and Escudero questionnaire (1998) to evaluate the students' attitude towards mathematics in the compulsory secondary school (ESO); and the work "Usemos las encuestas a los alumnos para mejorar nuestra docencia" ("Let's use the surveys given to students to improve our teaching") by Barrado, Gallego \& Valero-García (1999).

Qualitative data: Nine interviews, three for each institution, were conducted. The students who participated were also chosen randomly from the class lists. Once they accepted the invitation to participate, the parents' informed consents were completed, and the interviews were carried out in sessions that lasted between one and two hours. The objective of the interview was to expand and deepen the information collected in the survey on the aforementioned variables. The interviews provided valuable qualitative information about the activities that take place in the classrooms, the relationships among the students as peers and between them and the teachers, and the students' opinion about the usefulness of this subject.

\section{Validity and Reliability of data}

The data's margin of error used was of $0.5 \%$. To verify the validity and reliability of the questionnaire, two actions were taken: A pilot test was applied with a sample size calculated with the same computational program as the definitive instrument and subsequently submitted to be evaluated by an expert. The pilot test was given to one hundred students from the three participating schools in the research. This allowed us to adjust and rectify the initial questionnaire. Among the most significant adjustments, the most noteworthy were: decreasing open questions, modifying answer options to avoid generating ambiguity, replacing some terms that the students found hard to understand, reformulating some questions that confused the students, and including questions that the students considered important. In conclusion, the pilot test was very useful to consolidate and rectify the questionnaire that was finally applied.

The second action to test the validity of the interview consisted in an external evaluation. The script of the interview was submitted to an expert in educational qualitative research methods. This evaluation was very useful and allowed for a reorientation of the questions initially posed. The expert pointed out that some questions could generate bias and/or confusion in the students, and that they needed more clarity and further explanation. He suggested taking into account the level of abstraction required in relation to he students' stage of development. In conclusion, this evaluation led to the improvement of the script that was initially proposed.

\section{Data processing and analysis}

Quantitative data: Data collected in the survey were digitized, reviewed and finally subjected to descriptive and inferential statistical processes using the Stata program. With part of the data, frequency measurements were made, based on the students' answers, and bar diagrams were drawn to represent data of qualitative or discrete variables. These diagrams consisted in rectangular bars in which the height was 
proportional to the frequency of each of the values for each variable. Finally, to predict the likelihood that students enjoy and feel motivated by the social science class, a logistic model was applied (Logit Model), whose data was plotted with the ROC Curve. These graphs indicate the capacity of a model to predict an event accurately.

Qualitative data: Two stages were required to systematize the interviews: one for transcription; the other for theming. In the first, the content of each of the nine interviews was transcribed literally; in the second, a matrix with fragments of the answers was created. The task of systematization required a labeling and coding of the fragments according to the variables already mentioned. Once this was accomplished, an analysis of the data in the Nvivo program was performed. This analysis enabled us to identify the variables to which students gave greater importance in the interviews and to establish subcategories within each variable according to the frequency and number of student interventions.

\section{FINDINGS}

As a result of the qualitative and quantitative data analysis, it was determined that the social science students' perceptions can be organized in relation to four topics: the methodology used by the teacher, the contents, the relationship between teacher and students, and the evaluation process.

Figura 1

Graphic distribution of the variables depending on the times they were referenced by students in the interviews. Author's elaboration

Table 3

Graphic distribution of the variables depending on the times they were referenced by students in the interviews.

\begin{tabular}{llll}
\hline Codes & Categories & $\begin{array}{c}\text { Number of } \\
\text { references }\end{array}$ & $\%$ \\
\hline CSAE.QA.6 & Components to add and remove in the class & 5 & $3 \%$ \\
CSAE.OP.2 & Opinion about the teacher & 17 & $11 \%$ \\
CSAE.OC. 1. & Opinion about the class & 30 & $19 \%$ \\
CSAE.IUC.4 & Importance and utility of the contents & 5 & $3 \%$ \\
CSAE.CI. 7. & The ideal class & 6 & $4 \%$ \\
CSAE.CC.3 & Class contents & 16 & $10 \%$ \\
CSAE.AI.10 & Perceptions about school and education & 6 & $4 \%$ \\
CSAE. MP.5. & Teachers' methodology & 50 & $32 \%$ \\
CSAE. EPS.9. & Assessment and Saber test & 20 & $13 \%$ \\
CSAC.ME.3 & Motivation toward the study of social sciences & 1 & $1 \%$ \\
& & &
\end{tabular}

Author's elaboration

Figure 1 and Table 3 show that $32 \%$ of student references have to do with teaching methodologies, $19 \%$ to positive or negative opinions about the class, $13 \%$ to the evaluation process, $11 \%$ to opinions about the teacher, and $10 \%$ to the contents of the class. 


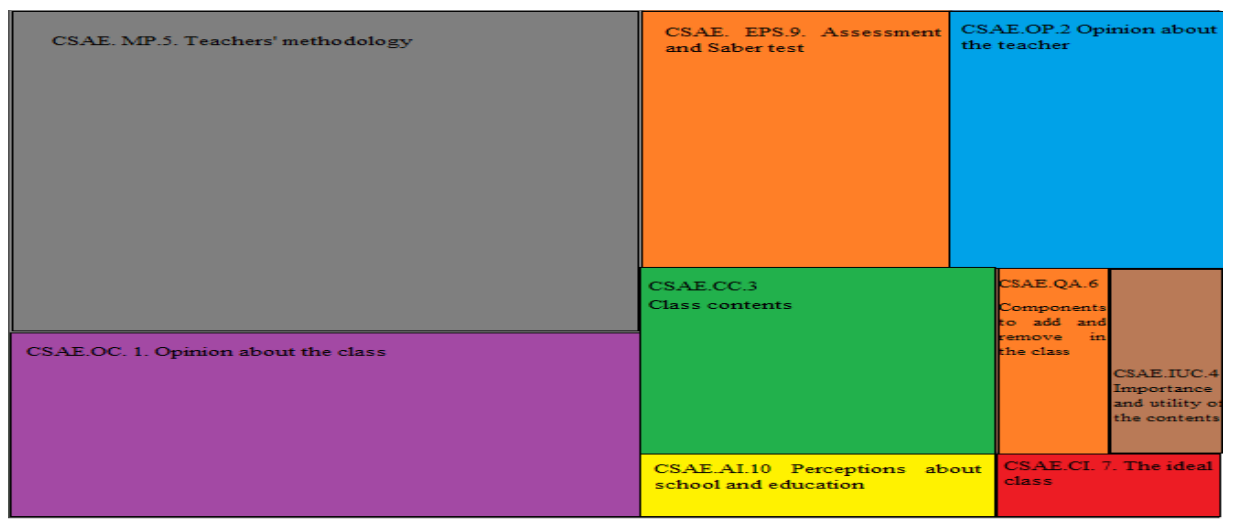

Figure 2 illustrates the methodologies mostly used by teachers. The one with the highest percentage is the workshop with $89.7 \%, 44.8 \%$ and $62.1 \%$ in Institutions I, II and III respectively, and with a $62.8 \%$ in the total amount.

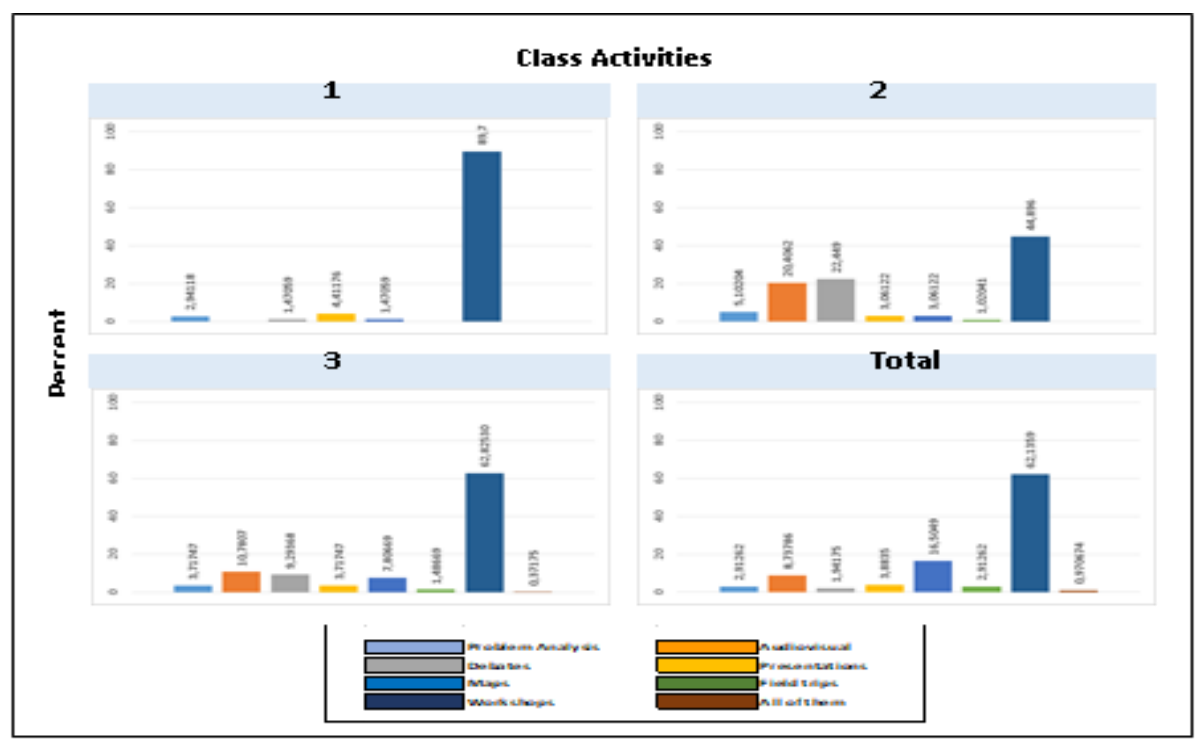

Figure 2

Teachers' methodologies Author's elaboration

Students define as workshops, activities in which teachers ask them to transcribe and answer questions from textbooks or from a guide provided by the teacher, usually photocopied from a textbook. With some variations between the three institutions, other activities, such as mapping, debates and audiovisual material have maximum percentages of $22 \%, 20 \%$, and $16 \%$. Activities such as problem analysis, exhibitions and pedagogical field trips have the lowest scores. Of the 50 references given by students in the interviews regarding the teacher's methodology (Figure 1), 37 indicate that because 
of these methodologies, classes are monotonous and boring. "The worst are the workshops. I hate them." "We spend all our time doing workshops and answering questions that they never check." "The teacher arrives, explains for just a few minutes, hands out some photocopies, and dictates some questions that we have to answer. The whole year is like this." Ten references indicate that the teacher performs motivating activities, and three relate methodology with the teacher's charisma.

Of the 20 references regarding the evaluation process, 13 indicate that students focus this process on the performance of exams that help them obtain good results in the Saber tests. According to the students, much of the time is spent on getting them acquainted with exams similar to the Saber tests and in identifying the correct and wrong answers, without necessarily learning. Seven references indicate that the evaluation is easy because the class is also very easy. They classify social science as one of the subjects in which no big effort is required and good grades are obtained. The following are some of the opinions: "We go there to relax"; "We all play with our cell phones"; "It's a very easy class"; "You just give your opinion, and you pass the subject"; "Most of us study only to pass the exam." The other two references mention that the evaluation process helps students improve their performance in class.

Regarding the contents of the class, in the survey, the students were asked about the proportion in which the teachers implement the thematic axes proposed by the Ministry of Education. As illustrated in Figure 3, with some variations between the three institutions, all students agree that history and cultures are the most studied subjects in class; geography and environment as well as economic activities occupy the second or third place, and in all cases, topics about political organizations and institutions are in the last place.

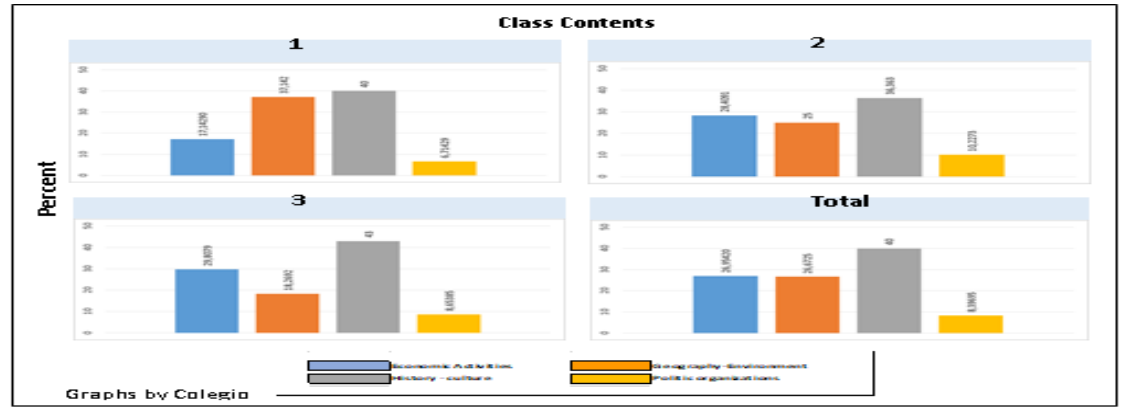

Figure 3

Class contents. Author's elaboration 


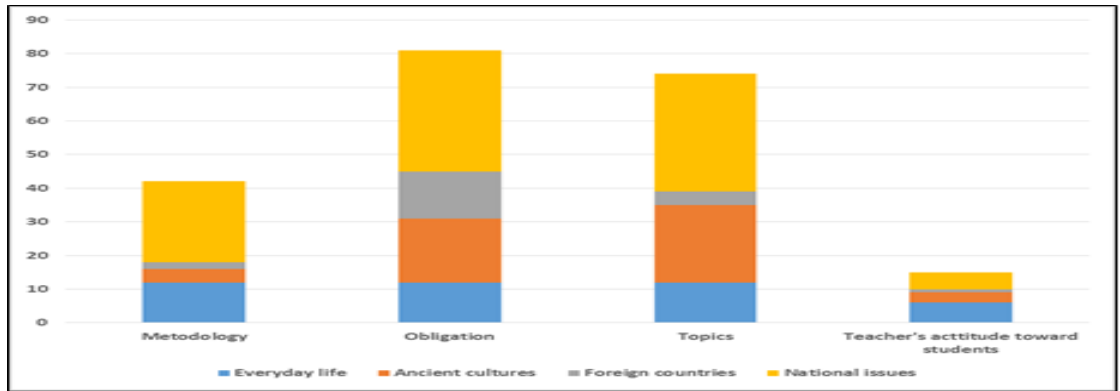

Figure 4

Students' opinions about their motivations to go to class and topics they would like approach. Author's elaboration

When the question about the reasons for enrolling in a class is combined with the topics that the students would like to address (Figure 4), it is evident that according to the majority, $80 \%$ enroll because it is compulsory; the topics proposed and the methodology used are the next two reasons, with $72 \%$ and $41 \%$ respectively. Finally, the way the teacher treats the students occupies the last place with $23 \%$. National and daily life issues are topics that students would like to work on in the social science class, followed by ancient cultures and issues about foreign countries.

On the other hand, of the 16 references in the interviews about the contents in class, seven indicate that they do not delve enough into the subject. According to them: "Everything is very basic." "The topics are barely seen, superficially, and in a rush." There are six references that state that they are repetitive: "Every year, it's the same thing." "They repeat and repeat the same thing, and that is boring for the students." In three references, students affirm that the topics are relevant to the grade they are in. There were five references regarding the importance and usefulness of the contents: four of them emphasized the fact that what is taught has nothing to do with their life experiences and therefore has no applicability, and one considers that what they see in class is relevant. Some of the students' comments were: "They should teach us useful things, such as why there is poverty in Colombia or about the causes of violence"; "I would like to learn about teen pregnancy, gangs, corruption of politicians"; "I believe that people don't like the social science class because they are always talking about the past and not about what is happening today, which is what we are interested in."

Regarding the teachers, of the 17 references obtained from the interviews, seven indicated that teachers work in the institutions to earn a salary but show no commitment or dedication to their work. Some students say that teachers are disappointed in their profession because of the low salaries they receive and also because they feel that neither the state nor society recognizes the value and importance of their work. "They only care about their salary"; "They work because they have to"; "She doesn't like being a teacher, and she's frustrated". These are some of the comments made by students. Five references indicate that the teacher's personality traits are decisive in building a good learning environment: "The class is boring, but the teacher is very nice." "We go to 
class because the teacher is good and kind to us." Five students reported that they had good teachers who cared about teaching, were very committed to their work and also treated them well."

Finally, the students were asked in the survey about the skills and knowledge that in their opinion should be developed in class. Although there are some variations among the three institutions, the analysis indicates that for $34 \%$ of the total amount of participants, understanding the world in which they live is the most important skill for students; for $23 \%$, being educated people; for $20 \%$, knowing what is happening in the context of where they live and in distant contexts; for $12 \%$, finding a solution to social problems, and lastly, for $8 \%$, acquiring values.

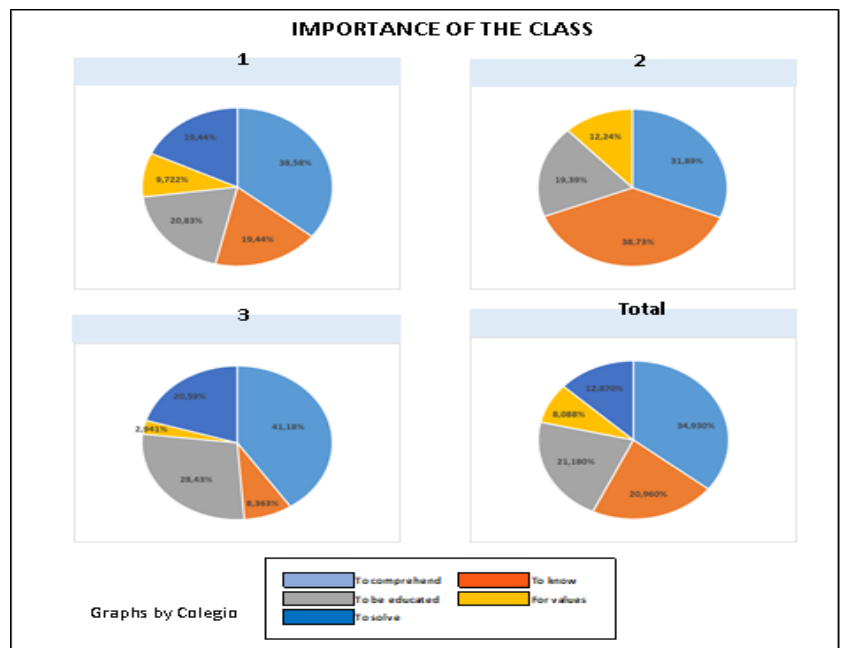

Figure 5

Development of skills that make the class important. Author's elaboration.

Of the 30 references in the interviews concerning opinions about the class, 19 indicate that it does not generate any enjoyment or motivation, that they attend because they have to, and that it is just another class. "You don't feel like going to class"; "People go to sleep and relax"; "They teach things from ancient times and far-away places. What does that matter? What is the use of studying that?" Seven references state that some aspects of the institutional life and actions taken by the State have a negative effect on the class. The following examples illustrate this point: "Since the school is so messy and everyone does what he/she wants, and there are no rules, we learn very little." "Look, the government doesn't invest in education; they don't send computers or fix the school. Who would want to be in class with those old books from many years ago?" "Frankly, we know very little about social sciences. If a teacher leaves, it takes a long time before another one comes, and during that time, we have no classes." The last four references mention that there are positive things and that the class provides useful knowledge for different life situations. For example: "It is good to learn social science because when 
you travel and the guide talks about something you already know, you can ask questions." "I want to go to the university, so I think the social science class is going to help me a lot; those who do not like it are those who come to school to have a good time and do nothing."

After reading the students' responses to both survey and interviews, we decided to implement two logistic probability models that would indicate under what circumstances students could have a good opinion and better expectations about the class.

Table 4

Logit Model estimate

\begin{tabular}{|c|c|c|}
\hline Variables & Opinions about the class & Expectations about the class \\
\hline Gender & $\begin{array}{l}0.173 \\
(0.398)\end{array}$ & $\begin{array}{l}-0.167 \\
(0.372)\end{array}$ \\
\hline Socioeconomic strata & $\begin{array}{l}0.219 \\
(0.284)\end{array}$ & $\begin{array}{l}0.0933 \\
(0.246)\end{array}$ \\
\hline Motivation to go to class & $\begin{array}{l}1.661 * * * \\
(0.420)\end{array}$ & $\begin{array}{l}0.628 \\
(0.395)\end{array}$ \\
\hline Importance of the class & $\begin{array}{l}-0.0153 \\
(0.134)\end{array}$ & $\begin{array}{l}-0.177 \\
(0.129)\end{array}$ \\
\hline Teaching they receive & $\begin{array}{l}0.482 \\
(0.484)\end{array}$ & $\begin{array}{l}1.050 \text { *** } \\
(0.399)\end{array}$ \\
\hline New knowledge & $\begin{array}{l}0.744 \\
(0.544)\end{array}$ & $\begin{array}{l}1.353^{*} \\
(0.738)\end{array}$ \\
\hline Class contents & $\begin{array}{l}-0.0430 \\
(0.209)\end{array}$ & $\begin{array}{l}0.00669 \\
(0.182)\end{array}$ \\
\hline Increase of knowledge & $\begin{array}{l}0.121 \\
(0.392)\end{array}$ & $\begin{array}{l}0.606 * \\
(0.367)\end{array}$ \\
\hline Development of skills & $\begin{array}{l}0773 * \\
(0.402)\end{array}$ & $\begin{array}{l}0.840 \text { ** } \\
0.401\end{array}$ \\
\hline Class activities & $\begin{array}{l}-0.0261 \\
(0.100)\end{array}$ & $\begin{array}{l}-0114 \\
(0.0883)\end{array}$ \\
\hline Time dedicated to homework & $\begin{array}{l}0.190 \\
(0.111)\end{array}$ & $\begin{array}{l}-.113 \\
(0.105)\end{array}$ \\
\hline Father's educative level & $\begin{array}{l}-0.157 \\
(0.111)\end{array}$ & $\begin{array}{l}-0.0330 \\
(0.105)\end{array}$ \\
\hline Mother's educative level & $\begin{array}{l}0.0894 \\
(0.122)\end{array}$ & $\begin{array}{l}0.165 \\
(0.113)\end{array}$ \\
\hline Life stimulus & $\begin{array}{l}0.728^{*} \\
(0.442)\end{array}$ & $\begin{array}{l}0.226 \\
(0.226)\end{array}$ \\
\hline Objectives of the class & $\begin{array}{l}0.327 \\
(0.450)\end{array}$ & $\begin{array}{l}1.648 * * * \\
(0.519)\end{array}$ \\
\hline Constant & $\begin{array}{l}-3.710 * * \\
(1.462) \\
\end{array}$ & $\begin{array}{l}-3.853^{* * *} \\
(1.396) \\
\end{array}$ \\
\hline Total observations & 275 & 275 \\
\hline
\end{tabular}

Standard errors in parentheses $* * * \mathrm{p}<0.01, * * \mathrm{p}<0.05, * \mathrm{p}<0.1$. Author's elaboration 


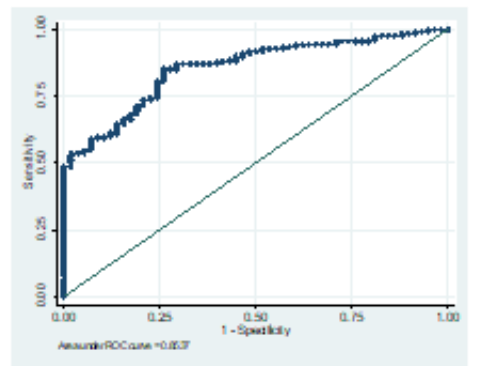

Figure 6

Adjustment to the model of opinions about the expectations about the class

Authors' elaboration

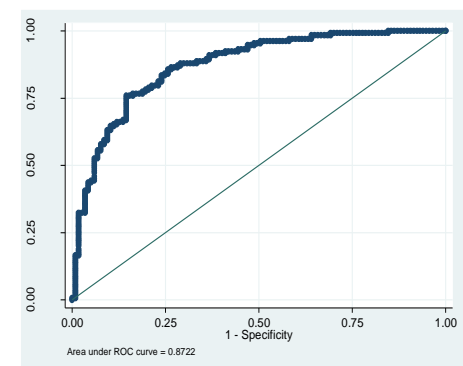

Figure 7

Adjustment to the model of the class

Author's elaboration

Figures 6 and 7 gave estimation values of 0.85 and 0.87 , indicating a good predictive power for both models. The Logit Model estimate, whose predictor variable is the students' opinion (Figure 6), made it possible to determine that, if a student enrols in a social science class by his/her own preference and not because it is mandatory, the probability of having a positive opinion of the class increases by an average of 20 percentage points. If the student considers that the social science class helps him/her develop his/her abilities, the probability of having a positive opinion of the class increases by an average of nine percentage points. If the student considers that the social science class stimulates the desire to go as far as possible in his/her academic interests, the probability of having a positive opinion of the class, increases by an average of nine percentage points.

Following this same trend, the Logit Model (Figure 7), whose predictor variable is the students' expectations, indicates that when a student considers that his/her interest in social sciences increased because of what he/she learned, the probability of perceiving that the subject meets his/her expectations increases, on average, 15 percentage points. If the student considers that social science contributes to acquiring new knowledge, the probability of perceiving that the subject meets his/her expectations increases, on average, 19 percentage points. If the student considers that the work he/she performs in the social science class motivates him/her to broaden his/her knowledge outside the school premises, the probability of perceiving that the subject meets his/her expectations increases, on average, 8.75 percentage points. If the student considers that the social science class helps him/her develop his/her abilities, the probability of perceiving that the subject meets his/her expectations increases, on average, 12 percentage points. If the student considers that the objectives of the subject are clear and well defined, the probability of perceiving that the subject meets his/her expectations increases, on average, 24 percentage points.

\section{DISCUSSION AND CONCLUSION}

The data from the interviews and surveys carried out with students in their last year of the Colombian secondary schools that participated in this research indicate that negative 
perceptions prevail over positive ones, regarding methodologies, contents, the figure of the social science teachers, and the evaluation process These perceptions generate little or no motivation in students towards the subject; they are the result of non-significant school experiences in their classes during the primary and secondary school cycles.

The opinions voiced by the students are reiterative in that the class is important and could help them enhance their capacities and understanding of the world in which they live, but the methodologies, the contents, and the evaluation methods are not the most appropriate. In addition, some conflicts with the teachers' personalities exist. This corroborates Mateos's approach (2009), according to which even if in most cases the objectives and contents of teaching are not presented to the students in a clear and explicit way, the intentions that underlie the activities and the guidelines received by the teachers, can be perceived by the students throughout the educational process.

The two models of probabilities and applied logistics (Figures 6 and 7) indicate that an increase in positive opinions and expectations by the students towards the social science class is directly related to clear objectives in the class, generating liking and motivation, making the students feel that they are developing their skills and that what they are being taught will be useful and necessary to help them achieve their goals. Consequently, it is evident that there is a need to rethink several things: The way in which social science classes are being implemented, how the content is being organized and presented, and the type of activities and forms of evaluation proposed to students. Also, the role of the teacher as a guide to the teaching and learning processes of the subject must be revised.

Students understand by methodology the learning activities that teachers propose in the classrooms. The prevalence of this topic over others in the interviews (Table 3 and Figure 1) denotes the influence of this factor on the students' negative perceptions. In the three schools, what students call "workshops" is not only the most frequent activity, but also the most boring one, as indicated by the students in the interviews. The "workshops" are reduced to transcriptions of information or solving questions in textbooks or photocopies brought by the teacher. In addition to how insignificant and unchallenging students find these workshops, they also believe them to be a source of discomfort and dislike because the class becomes monotonous and repetitive, their work is limited to "catch" answers in some texts, and mostly, these answers are neither reviewed nor discussed.

Thus, the use of the textbook is usually associated with the demotivation of students and with empowering the capacity of memorization. The plan followed in the classrooms, as described by the students in the interviews we conducted, is similar to the one identified by Delgado (2012). The class begins with the presentation of the theme by the teacher, followed by an explanation of some concepts and guidelines for reading the textbook and answering the "workshops". What is striking is that despite all the criticism, this practice is still the most widely used by many teachers of social science and other subjects. Our findings on the significance of the use of the textbook and the consequent "preparation of workshops" coincide with those of Vera, Morena and Torres (2014). In their work with Spanish history students, they also identified that, unlike other activities, questions answered in textbooks are still widely used by teachers. For these authors, the 
main limitation that this entails is that teachers deposit all didactic action in the textbook, limiting themselves to indicating the contents that are worth highlighting or underlining, or to a simple formulation of questions.

Field trips, debates on current issues and analysis of daily life problems are some of the methodologies, which according to the students would not only enhance their abilities, but would also make the class more pleasant and participatory. Alonso Tapia (1999); De Miguel (2006); Fernández (2006); Coll (2010); Pujolàs (2008) and Bolarín, Méndez and Porto (2014) and Carle, Bruno and Di Risio (2014), are some of the authors who have advocated methodological diversity in social science classes. These authors stress the importance of fleeing from the routine and proposing different tasks that offer new perspectives of realities and possibilities of multiple actions. In their opinion, this approach not only arouses curiosity in the students when starting a new topic, but also favors the richness of learning it in its wholeness.

On the evaluation of learning, as manifested by the interviews and survey data, only a very small number of participants perceives it as a process that contributes to improving teaching and learning. Three things stood out: the process does not require that the students work harder since they can pass the subject with the least effort; they mostly study to pass the exams and not to learn; and, especially in recent years, teachers have been focused on teaching how to answer State tests in order to receive the incentives that the Colombian government grants teachers, students and institutions with high scores. In this same trend of thought, Bolarín, Méndez and Porto (2014) affirm that the evaluation is perceived as a source of demotivation due to the amount of time spent, the results, the type of tests and the low level required. According to these authors, students' answers show that it is more an evaluation of results than of processes, and that it is mainly focused on monitoring the ability to express the contents in the most similar way possible to what was explained or to what appears in the textbooks.

With regard to the contents, Alonso Tapia (2005) and Bolarín, Méndez and Porto (2104) emphasize the positive effect on the students' motivation when the teacher shows the usefulness of learning the content, organizes the class, and presents the topics with clarity. According to the data from the interviews and surveys, two points obtain very negative perceptions: the pre-eminence of quantity over quality and the insufficient usefulness and applicability the students consider that the content of the social science class has. In this regard, Gimeno (2012), González - Canabach, Valle, Núñez, González - Pineda (1996), and Bolarín, Méndez, and Porto (2014), state that traditionally the school has opted for an encyclopedic curriculum, large and shallow, which causes an amplitude of the programs in which knowledge is confused and identified with the rote memorizing of data, preventing students from correctly detecting the content, limiting their effort to studying to pass the exams.

With regard to the usefulness of the contents, Holton (2003), Gimeno (2012), González - Canabach, Valle, Núñez, González - Pineda (1996), Bolarín, Méndez, and Porto (2014), Laukenmann, Bleicher, Fub, Gläser Zikuda, Mairying and Von Rhöneck (2003), and Marbà and Márquez (2010) also state that part of the demotivation towards the social sciences is due to how little usefulness the students perceive in the theoretical 
contents, since, in most cases, the concepts do not relate to their interests. For these authors, if students believe that the contents studied will be useful for higher education courses or even for future work, they will be more motivated to assimilate and learn to apply them with ease. On the other hand, if they consider the contents to be useful only to pass an exam, and if they think that they will never use this knowledge again, that it can be forgotten after the exam, all motivation is lost.

Finally, it is important to emphasize the great importance of what the teacher represents in how students perceive their social science class. Students have a very clear notion of what a competent teacher should be; that is, one who, above all, favors learning (Mateos, 2009). There are three aspects regarding the teachers that the students highlighted: the desire to teach, and their knowledge of the topic and pedagogical skills. In other words, these three aspects are as; the teacher's competence, the influence that his/her personality has on the class and the type of relationship established between teacher and students.

Bolarín, Méndez, and Porto (2014), Weinstein (1997), Núñez (2007), and Lafout (1999) have determined that, for students, competent teachers are those capable of creating environments that generate learning, and of planning, organizing and proposing tasks that do not correspond to traditional methodologies in which students have a passive role. These authors also believe that teachers' competence has to do with transmitting passion and joy for the subject they teach and the job they hold. In the interviews for this research, we found expressions like: "He is an excellent teacher who knows a lot and tries to make us learn." "The $9^{\text {th }}$ grade social science teacher was good. She prepared her classes well, was very organized in the classroom, liked to teach and really tried to make us learn. It's a shame she only taught us for one year." Teachers who transmit their enthusiasm and desire for knowledge, who pose challenges to the students and encourage them to face them, are competent (Delgado, 2012).

Concerning the influence that the teacher's personality has in creating a good learning environment, it was a novelty to identify the importance it had in the students with whom we worked. They emphasized that although the contents of the subject and even the methodologies are not the most striking, the empathy felt for the teacher becomes an incentive to participate in classroom activities. "Social science is not my favorite subject, but the teacher is very human; he treats us well; he is attentive and that helps us in his class." "The topics are not very interesting and at times, they make you sleepy, but the teacher's good mood and joy end up encouraging us too." As these fragments of the interviews reveal, students value positively the teacher's personality and a good classroom environment. Teachers who are kinder and more tolerant draw the attention of their students. They create a good classroom environment that makes students feel comfortable when learning, and increase their interest in studying the subject (Vera, Moreno and Torres, 2014).

Closely related to the previous aspect is the type of relationships that teachers favor with students in the classrooms. Palacios (2013 and 2017) concluded that since Colombian secondary school students became aware of the rights granted by law, they do not allow teachers to mistreat them. Students interviewed say that they can "put up with a teacher 
that has poor knowledge of the topic he/she teaches, but being mistreated is out of the question." Carrillo, Leal, Alcocer and Morgan (2010), Mateos (2009) and Lozano (2005) have established, in their respective research papers, that some students perceive that the incongruence between what teachers say and what they do is one of the main causes of what teachers themselves consider disrespectful. Students believe that it is not possible to pretend to teach values when there is a systematic lack of respect or intolerance between teachers and students. The latter consider that most of the efforts aimed at teaching them values such as politeness, remain in the teachers' oral and theoretical exposition.

\section{Some suggestions}

The study shows that social science teaching needs to be enriched with studies that gather students' perceptions about what goes on in school life and, more specifically, in the classrooms. The research also indicates the importance of delving more profoundly in secondary school students' perceptions regarding their classes. This implies understanding that students conceive social science teachers' methodology to be directly linked to their personality, to their motivation for work and to the interest they manifest towards the students' learning.

It is suggested that both the faculties of education as the training schools for social science teachers focus their attention on the orientation of teaching methodologies for future teachers. This work reveals that disciplinary knowledge is not enough. Teachers must also demonstrate skills and abilities to implement methodologies that students find attractive and that generate expectations and a desire to learn.

Consequently, the trainers of future teachers and the training programs for those who are already working must also be engaged in preparing students in the design of the implementation of more challenging, highly cognitive, procedural and attitudinal learning activities. The vision of the students consulted in this research indicates that proposing tasks that students consider easy and that do not generate any level of difficulty, causes demotivation for the class and resistance to the figure of the teacher.

Equally important as the above, is that future teachers and those already working be trained in the emotional management of the classroom. This study evidenced that in the case of social sciences, a conflictive environment, a relationship of rivalry, and little empathy between students and teachers, can be negative factors that slow down and impede the learning processes.

\section{REFERENCES}

Aldrich, R.E. (1987). Interesting and useful. Teaching History, 47, 11-14.

Alonso Tapia, J. (1999). Motivación y aprendizaje en la enseñanza secundaria. En Coll, C. (coord.). Psicología de la instrucción: la enseñanza y el aprendizaje en la Educación Secundaria, pp 105-139. Barcelona:Horsori/Universitat de Barcelona/Instituto de Ciencias de la Educación. 
Alonso Tapia, J. (2005). Motivación para el aprendizaje. La perspectiva de los alumnos. En La orientación escolar en centros educativos, pp 209-242. Madrid: Ministerio de Educación y Ciencia de España

Arnot, M. y Reay, D. (2007). A sociology of pedagogic voice: power, inequality and pupil consultation. Discourse: studies in the cultural politics of education, 28 (3), 311325.

Barca, I. (2005). Till New Facts Are Discovered: Students'Ideas about Objectivity in History. In: Ashby, R., Gordon, P. y Lee, P. (eds) Understanding History: Recent Research in History Education. International Review of History Education, vol. 4, pp, 68 -82 Nueva York: Routledge - Falmer.

Bar-Gal, By Sofer, S. (2010). Israeli students' perceptions of geography instruction goals. International Research in Geographical and Environmental Education, 19 (2), 127-137.

Barton, K (2005). "Best Not to Forget Them": Adolescents' Judgments of Historical Significance in Northern Ireland. Theory and Research in Social Education. 33, 9-44.

Bolarín, M.J, Méndez, R y Porto, M. (2014). La motivación de los estudiantes para el aprendizaje de la historia: referentes y resultados En Martínez, N. (Dir). La historia de España en los recuerdos escolares. Análisis y poder de cambio de los testimonios de profesores y alumnos, pp 157-176. Valencia: Nau Llibres.

Bowlick, F. y Kolden, C. (2013). Effects of an introductory geography course on student perceptions of geography at the University of Idaho, Journal of Geography in Higher Education, 37 (4), 515-535.

Carle, G., Bruno, J. y Di Risio C. (2014). ¿Qué piensan nuestros alumnos de la química? Una experiencia de indagación a estudiantes de la escuela media en la provincia de Buenos Aires Argentina para el diseño de estrategias didácticas. Ponencia presentada al Congreso Iberoamericano de Ciencia, Tecnología y Educación. Buenos Aires Argentina, 12, 13 y 14 de noviembre.

Carrillo, M., Leal, M., Alcocer, M. y Morgan, J. (2010). Percepción del estudiante sobre el trabajo en el aula: El caso de una carrera universitaria. Revista de Educación y Desarrollo, 15, 13-20.

Coll, C. (coord.) (2010). Desarrollo, aprendizaje y enseñanza en la Educación Secundaria. Barcelona: Graó

Cooper, H. (1992). Young children's thinking in history. Teaching History, 69, 8-13.

Evans, R. (1993). Ideology and the teaching of History: Purposes, practices and student beliefs. En: Brophy, J. (Ed) Cases studies of teaching and learning in Social Studies. Advances in Research on Teaching, 4, pp.179-214. Muncie: Ball Estate University. 
Delgado, P. (2012). Percepciones y valoraciones de estudiantes de Ciencias de la Educación UNNE acerca de las prácticas de enseñanza de sus profesores. Revista del Instituto de Investigaciones en Educación, 3(3). 5-14.

De Miguel, M. (dir.) (2006). Modalidades de enseñanza centradas en el desarrollo de competencias. Orientaciones para promover el cambio metodológico en el espacio Europeo de Educación Superior. Oviedo: Ediciones de la Universidad de Oviedo.

Fernández, A. (2006). Metodologías activas para la formación de competencias. Educatio siglo XXI, 24, 35-56.

Fuentes, C. (2002). La visión de la historia por los adolescentes: Revisión del estado de la cuestión en Estados Unidos y el Reino Unido. Enseñanza de las ciencias sociales, 1, 55-68.

Giménez, E., Ávila, J. y Ruíz, F. (2007). Concepciones sobre la enseñanza y difusión del patrimonio en las Instituciones Educativas y los Centros de Interpretación. Estudio Descriptivo. Enseñanza de las Ciencias Sociales, 6, 75, 94.

Gimeno, J. (2012). Educarse en la era digital. Madrid: Morata

Gómez, C. Miralles, P. y Molina S. (2015). Evaluación, competencias históricas y educación ciudadana. Revista de Estudios Sociales. 52, 52-68.

González-Cabanach, R.; Valle e, A.; Núñez, J. C. y González-Pineda, J. (1996). Una aproximación teórica al concepto de metas académicas y su relación con la motivación escolar. Psicothema, 8(1), 45-61

Grant, S. (2001). It's Just the Facts, or Is It? The Relationship between Teachers' Practices and Students' Understandings of History. Theory and Research in Social Education. 29, 1, 65-108.

Holton, G. (2003). The Project physics course, then and now. Science and education, $12,179,186$.

Kerlinger, F. (2002). Investigación del comportamiento. Métodos de investigación en ciencias sociales. México: McGraw-Hill

Laukenmann, M., Bleicher, M., Fub, S., Gläser Zikuda, M. Mairyng, P. y Von Rhöneck, C. (2003). An investigation of de influence of emotional factor on lerning in physics instruction, International Journal of Science Education, 25 (4) 489-507.

Lee, P. y Ashby, R. (1987). Discussing the evidence. Teaching History, 48, 13-17.

Lozano, J. (2005). Los significados de los alumnos hacia la escuela secundaria en México. Revista Iberoamericana de Educación, 36(9), 1-9.

Lumpkin, A., Achen, R. y Dodd, R. (2015). Focusing Teaching on Students: Examining Student Perceptions of Learning Strategies, Quest, 67 (4), 352-366.

Mateos, T. (2009). La percepción del contexto escolar. Una imagen construida a partir de las experiencias de los alumnos. Cuestiones Pedagógicas, 19, 285-300. 
Marbà Tallada, A. y Márquez, C. (2010). ¿Qué opinan los estudiantes de las clases de ciencias? Un estudio transversal de sexto de primaria a cuarto de la ESO. Enseñanza de las ciencias, 28(1)19-30.

Pagès, J. (1993). El Disseny, el desenvolupament del curriculum i el pensament del profesor: el caso de la experimentacio del' currículum de ciències socials del cicle superior' EGB a Catalunya. Barcelona:Universitat Autònoma de Barcelona.

Palacios, N. y Herrera, J. (2013). Subjetividad, socialización política y derechos en la escuela. Magis, Revista Internacional de Investigación en Educación, 5 (11), 413-437.

Palacios, N. (2017). Prácticas políticas en la escuela: Un estudio en tres instituciones educativas de secundaria en Colombia. Revista Última Década, 46, 213-257.

Portela, A., Martínez, N. y García M. (2014). La voz de los alumnos como testimonio vivo. En Martínez, N. (Dir). La historia de España en los recuerdos escolares. Análisis y poder de cambio de los testimonios de profesores y alumnos, pp 101-124. Valencia: Nau Llibres.

Pujolás, P. (2008). La calidad en los equipos de aprendizaje cooperativo. Algunas consideraciones para el cálculo del grado de Cooperatividad. Revista de Educación, 349, 225-239.

Rappoport, L. (1986). La personalidad desde los 6 a los 12 años. El niño escolar. Barcelona: Paidós.

Reeves, F. (1978). Alienation and the secondary school student. Educational Review, 30 (2), 139-148.

Rudduck, J (2006). The past, the papers and the project. Educational Review, 58(2), 131-143.

Rudduck, J (2007). Student voice, student engagement, and school reform. En Thiessen, D. y Cook-Sather, A. (Eds.). International handbook of student experience in elementary and secondary school. Dordrecht: Springer, 587-610.

Rudduck, J. y Flutter, J. (2000). Pupil participation and pupil perspective: 'carving a new order of experience'. Cambridge Journal of Education, 30(1), 75-89

Ruudd uck, J. y McIntyre, D. (2007). Improving learning through consulting pupils. London: Routledge.

Sáiz, J. y López Facal, R. (2015). Competencias y narrativas históricas. El pensamiento histórico de estudiantes y futuros profesores. Revista de Estudios Sociales, 52, 87-101.

Saleh, E. y Gandy, S. (2015). Perceptions of geography students in the USA and Egypt on global issues, Intercultural Education, 26 (5), 377-396.

San Fabián, J. (1988). Percepción de la escolaridad por el alumnado al final de la E.G.B. Madrid: Centro de Publicaciones del Ministerio de Educación y Ciencia de España. 
Sapiaims, R. y Zuleta P. Representaciones sociales de la escuela en jóvenes urbanos populares desescolarizados. Última Década, 15. 53-72.

Schutz, A. (1962). El problema de la realidad social. Buenos Aires: Amorrortu.

Secil, S. (2014). Turkish Primary Students' Perceptions of Geography, Journal of Geography, 113 (4), 160-170.

Seixas, P. (1993). Historical significance among adolescents in a multicultural setting. Curriculum Inquiry, 23(3), 5-13.

Shemilt, D. (1987). Adolescent ideas about evidence and methodology in History, en Portal, C. (ed.). The history curriculum for teachers, pp39-61. Londres: The Falmer Press.

Smyth, J. (2007). Toward the pedagogically engaged school: listening to student voice as a positive response to disengagement and 'dropping out'? En Thiessen, D. y CookSather A. (eds.). International handbook of student experience in elementary and secondary school, pp.635-658.Dordrecht: Springer.

Smyth, J. y McInerney, P. (2012). From silent witnesses to active agents: student voice in re-engaging with learning. Nueva York: Peter Lang.

Thornton, S. (1991). Teachers as Curricular- Instructional Gatekeeper in social Studies. En: Shaver, J. (Ed). Handbook of Researches on Social Studies Teaching and Learning. A project of National Council for the Social Studies, pp 237-248. Nueva York: MacMillan.

Vansledright, B. y Christine, K. (1998). Reading American History: the influence of multiples sources on six fifth graders. The Elementary School Journal, 98(3), 239-265.

Vera, M., Moreno, J y Torres, A. (2014). La enseñanza de la Historia en España: la percepción de los estudiantes en torno a las características de los docentes y su metodología En Martínez, N. (Dir). La historia de España en los recuerdos escolares. Análisis y poder de cambio de los testimonios de profesores y alumnos, pp 179-21. Valencia: Nau Llibres. 